\title{
The Benefits of e-Commerce before and during the Covid-19 Pandemic for Small Enterprises in Indonesia
}

\author{
SUKISNO SELAMET RIADI ${ }^{1}$, ARIESTA HEKSARINI $^{2}$, DIRGA LESTARI ${ }^{3}$, SITI MARIA $^{4}$, \\ SAIDA ZAINUROSSALAMIA ${ }^{5}$, RIZKY YUDARUDDIN ${ }^{6}$ \\ ${ }_{1,2,3,4,5,6}$ Faculty of Economics and Business, Mulawarman University, Samarinda, Indonesia.
}

\begin{abstract}
This study aims to analyze the benefits of e-commerce for small enterprises and its consequences before and during the COVID-19 pandemic. Furthermore, it examines the effects on the decrease in income of small enterprises and their response to a regulation restricting community activities. It also provides an outline of the support needed by small businesses. Meanwhile, a descriptive analysis and a paired t-test were used to analyze data (525 small enterprises in Indonesia) from an online questionnaire survey between May and June 2021. The results showed several significant discoveries, including the following: first, the COVID-19 pandemic resulted in a decline in revenue. Second, limits on community activities exacerbate the plight of small enterprises. Third, small enterprises sought several forms of assistance, with working capital accounting for the lion's share of requests. Finally, substantial variations exist in respondents' perceptions of the benefits of ecommerce before and during the COVID-19 pandemic. Furthermore, these results contribute to the small medium enterprises literature and have significant policy implications for developing countries.
\end{abstract}

Key-Words: - small enterprises, e-commerce, income, working capital, performance, COVID-19

Received: April 18, 2021. Revised: November 9, 2021. Accepted: December 9, 2021. Published: January 7, 2022.

\section{Introduction}

The COVID-19 pandemic has threatened the existence of most businesses regardless of their size. Small enterprises are in a much worse situation due to their financial constraints, limited client base, and reliance on a few key workers. They often lack access to public financial markets, which makes them more vulnerable to cash flow problems caused by revenue fluctuations. Furthermore, short-term cash withdrawals outweigh inflows, posing a threat to existence.

Small enterprises contribute significantly to the economies of many countries, and several studies show the contribution to the economy in European countries [1], Japan [2], Turkey [3] Colombia [4], India [5],[6], Lebanon [7] and Indonesia [8], [9], [10]. Moreover, In Indonesia, about 64 million SME actors, SMEs provided 61 percent of GDP and 97 percent of employment [11]. Therefore, small enterprises in Indonesia have become the focus of an interesting study during the COVID-19 pandemic.

One of the strategies used to support the sustainability of small enterprises and improve the economy in the face of a serious health crisis, is the adoption of e-commerce. The e-commerce market has grown to become the largest in Southeast Asia, accounting for over half of the region's entire market considering the size and its tech-savvy customers. Furthermore, mobile e-commerce adoption in selected Southeast Asian countries between July and October 2020 showed Indonesia as the country with the greatest adoption rate during the covid19 pandemic (See Figure 1). This situation offers small enterprises the opportunity to benefit from the adoption of e-commerce. However, $42 \%$ of the offline SMEs had time to shut down during the pandemic, and $24 \%$ of MSMEs operated online [12]

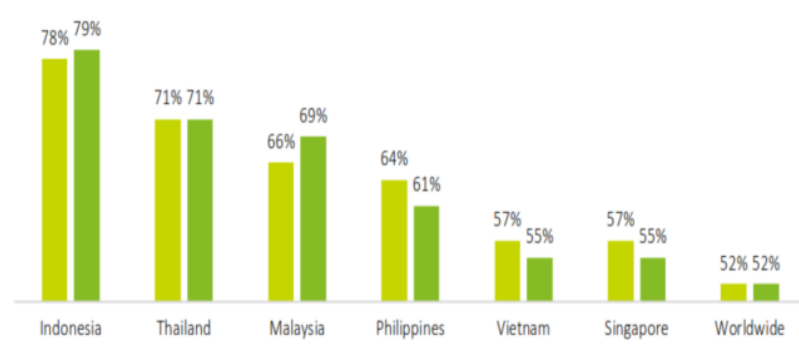

Fig.1: Adoption of mobile e-commerce in Southeast Asian countries between July and October 2020. Source: [12]

Moreover, the empirical study on the benefits of e-commerce adoption for small businesses has produced inconsistent findings. Mostly, the adoption is the key to the success of small enterprises [13] [14], [15], [16] [17], but does not support the performance [18], [19]. To address this gap, the 
benefits of e-commerce adoption for small enterprises were compared to gain a better understanding of the adoption in developing countries such as Indonesia.

To the best of our knowledge, only [13] identified the benefits of e-commerce for SMEs in Indonesia, but they did not conduct a study on the benefits of e-commerce for SMEs during a health crisis. Therefore, this study aims to explore the benefits of e-commerce for small enterprises before and during the COVID-19 pandemic. Scholars have emphasized the importance of e-commerce in improving the productivity and performance of SMEs. However, research regarding the use of ecommerce to address the consequences of catastrophic occurrences such as COVID-19 is sparse [20] We discuss this gap by provide empirical evidence for the benefits of e-commerce between before and during the COVID-19 pandemic. Additionally, it analyzes the decline in the influence of the pandemic on small enterprises' income and the reactions to the policy of restrictions of community activities. The result presents an overview of the forms of aid needed in the COVID19 pandemic for small enterprises. Overall, the goal of this research is to look into the advantages of ecommerce for small businesses before and during the COVID-19 epidemic.

\section{Literature Review}

Electronic commerce, or e-commerce is the practice of purchasing and selling goods and services through the internet. It involves actions such as the transfer of cash and the marketing of services or commodities. Businesses have the chance to reach many consumers as possible through e-commerce operations. There is no one definition, and according to [21], e-commerce is the online contact between a firm and its consumers or suppliers to place orders. The internet becomes a critical component of the business. It was also defined by [22] as the act of trading products, services, and/or information via computer networks, mainly the Internet and intranets. Meanwhile, [23] noted that ecommerce is the purchasing and selling of goods and services utilizing the internet and browsers. [24] argued that E-commerce is described as a business transaction performed between people using digital technologies. Media e-commerce also includes utilizing the internet, the World Wide Web, and mobile apps or browsers to do business. The mobile platform connects mobile devices such as tablets or smartphones and to the Internet through a wireless network or cellular telephone service. The first digital medium was a web browser. Currently, mobile apps are the most frequently utilized media [24].

The existing e-commerce literature has several hypotheses on the variables that influence SMEs' adoption of e-commerce. [25] were the first to create TRA (Theory of Reasoned Action), and it was stated that an individual's conduct is heavily influenced by the desire to execute the action. This is conducted following two factors: their attitude toward behavior and their subjective norm. Furthermore, [26] criticized this theory for its inability to accommodate a person that lacks volitional control. In response to these critiques, the Theory of Planned Behavior (TPB) was developed to address the limitations of TRA. [26] expanded TPB by including additional components known as Perceived Behavioral Control (PBC). Therefore, three variables affect one's desire to do a certain action: one's attitude toward the conduct, one's subjective norm, and one's perception of behavioral control. Furthermore, [27] created the TAM model based on the TRA network, which is specifically designed to account for an individual's computer usage behavior. According to this idea, actual conduct is strongly influenced by behavioral intention by both 'attitude toward' and perceived utility. Besides influencing behavioral intent, perceived utility and simplicity of use also affect attitude (toward). [28] created the Diffusion of Innovation Theory (IDT) model based on extensive psychological and sociological studies. According to this hypothesis, variables such as relative benefits, trialability, complexity, observability, and compatibility affect the pace of innovation adoption. Finally, [29] established the TechnologyOrganization-Environment (TOE) paradigm to explain the effect of contextual variables on the adoption of innovation. According to this paradigm, three elements of a firm's context affect the acceptance of technology innovations. They include technical, organizational, and external task environmental.

SMEs are very important in the local, national, and global economies, as well as in the generation of employment and revenue [30]. SMEs account for at least 90 percent of all enterprises in both advanced and emerging countries. Meanwhile, advanced countries account for 40-60 percent of global GDP, 40 percent of global industrial manufacture, and 35 percent of global exports [5], [31], [32]. Furthermore, they account for almost $99.8 \%$ of non-financial businesses, $58.6 \%$ of total value produced, and $68.6 \%$ of total employment in Europe [1]. In Turkey, 2014, they accounted for 
99.8 percent of all businesses, where exports and imports were 55.1 and 37.7 percent respectively [3]. In Japan, SMEs make up $99.7 \%$ of all companies and employ $70 \%$ of the workforce [2]. In addition, SMEs are critical to Colombia's economy since they account for 80 percent of jobs, 35 percent of GDP, and 90 percent of the productive sector [4]. In Indonesia, about 64 million SME actors, SMEs provided 61 percent of GDP and 97 percent of employment [11].

Business surveys show that the COVID-19 pandemic problem has serious havoc on SMEs, creating substantial disruptions and concerns. [33] report 43 percent of responding companies have already been forced to shut their doors temporarily in the United States. Businesses laid off an average of 40 percent of their workforce. [34] documented similar pandemic-related effects on small businesses. According to a study of SMEs conducted by the International Trade Centre, $2 / 3$ of micro and small enterprises in 132 countries believe that the crisis had a major effect. Meanwhile, onefifth of the population reported that they are at risk of permanently closing their business within three months. A pandemic's first four months, [35] show that between 25 percent and 36 percent of small companies may locked permanently following the different studies conducted in several nations. According to [36], the Census Bureau developed a specialized weekly small enterprises survey in the United States to evaluate the impact of COVID-19 on small enterprises. Late in June, the poll found that almost $90 \%$ of small companies were negatively affected by the pandemic, either severely (51 percent) or moderately ( 38 percent); 45 percent of enterprises faced supply chain interruptions, and 25 percent of firms lacked financial reserves of more than 1-2 months.

The COVID-19 pandemic had a detrimental effect on SMEs, and in West Java, Indonesia, [10] found that external factors such as competition and consumers had a negative impact on SME performance. [9] focused on the kinds of challenges encountered by SMEs during the pandemic, and it was reported that they suffered production difficulties. Due to a scarcity of raw materials, a lack of financial liquidity, and a drop in demand, this happened. Furthermore, [37] depicts the economic and social consequences of the COVID19 pandemic. A significant decrease in aggregate demand as a consequence of lower household and business expenditure, investment, and exports increased unemployment. Meanwhile, the government's fast and comprehensive reaction helped to minimize the crisis's effect on the economy and sensitive sectors of society. The pandemic worsened Indonesia's pre-existing basic issues, such as de-industrialization and the interregional digital gap. It was showed that the social distance policy has a significant effect on business players, especially SMEs. Furthermore, the inability to function properly has a negative impact on their operations, and this resulted in reduced demand and revenue [38].

Social isolation or distance are barriers that SMEs should overcome. In terms of economics, social distance has resulted in a reduction in SMEs' sales as a result of the prohibition of activities in public spaces. Furthermore, COVID-19 has impacted all facets, but there is a higher concern about instituting social lockdowns or distancing measures that disproportionately harm SMEs [39]. The results showed that the social distance policy has a substantial impact on business actors, particularly SMEs. In Indonesia, the operations are affected by their inability to function properly, resulting in decreased demand and income [38]. Due to this, various policies have been implemented to mitigate the impact of the health crisis on SMEs. For instance, [40] demonstrated that suspending interest payments has a negligible influence on company failures. [41] showed the importance of liquidity assistance for SMEs, however, the problem faced by small companies differs significantly among regions and cities in the United States. In Indonesia, liquidity is important for business support [56] [57] [58]. Furthermore, this study aims to determine the cash value and the liquidity SMEs required as well as to analyze the capacity of the business to take additional loans [42].

The advantages of e-commerce have been expanded in recent years due to advancements in information technology and communications. Furthermore, there is a greater understanding of online business to create market structure, decrease operational expenses, and connect consumers more effectively. Numerous studies have shown that the usage of digital technology, especially E-commerce, may have a role in determining the success of SMEs. Several studies have shown that e-commerce may help SMEs enhance their performance. [43] stated that it helps in the development of companies in underdeveloped countries to reduce transaction costs by bypassing certain intermediaries and enabling connections to global supply chains. Furthermore, e-commerce offers a plethora of benefits, ranging from minor benefits such as decreased communication and administrative expenses and increased accuracy to transformational ones such as allowing business process 
reengineering and facilitating industry value chain integration efforts [44]. [45] discovered that the growth of high-tech innovative SMEs is important to Ukraine's economic development. [13] showed that SMEs with a greater level of e-commerce adoption profit more than those with a lower level.

E-commerce assist SMEs financially and in terms of market expansion. Meanwhile, SME access to many major markets is often challenging due to entry criteria such as money, product variety, brand, or shares. They may get better access to these markets by using information technology. Also, online and digital businesses can help small businesses decrease their operating expenses [46] and the beneficial effects may also be felt through consumers and services [47]. Furthermore, the integration of information technology helps South African SMEs to operate better [48]. [49] demonstrated that e-commerce adoption affects the strategy of Saudi Arabian SMEs. In addition, restaurants may use the online ordering system to connect with their target audience in the United States [15]. In the Czech Republic, online technology allows the development and marketing of goods [14]. Technological advancement improves the performance of SMEs in the UK [17]. Additionally, [16] stated that marketing through social media had a positive impact on the performance of SMEs in Indonesia.

However, another study indicates that the performance of SMEs does not substantially improve e-commerce. [50] stated that the impact of technology adoption on operation costs varies by circumstance. Certain transaction costs may be decreased as a consequence of new technology adoption. Because of the extensive usage of the internet across all industries, it cannot be considered a source of competitive advantage due to the widespread use of the internet across all sectors [51]. According to [19], there is no compelling evidence to promote e-commerce benefits in South African businesses. [18] demonstrated that despite the advice to SMEs to participate in e-commerce applications, the strategic position of SMEs and their e-business skills do not seem to be linked. [52] observed that the relationship between e-commerce and the competitive advantage, which is the crucial component of the Strategic plan, is difficult for Egyptian manufacturing companies to comprehend.

Overall, to the best of our knowledge, only [13] found the benefits of e-commerce for SMEs in Indonesia, but they did not do a study on the benefits of e-commerce for SMEs during the COVID-19 pandemic. As a result, this study adds to the body of knowledge by demonstrating the importance of e-commerce to small enterprises.

\section{Methodology}

Quantitative and qualitative techniques were employed to examine the conceptual framework for studies and the challenges. The data was collected from 525 small enterprises. The information is drawn from an online questionnaire survey conducted from May 2021 - June 2021 among small culinary businesses. Furthermore, the online questionnaire survey has numerous advantages over traditional procedures, such as being less expensive, having a greater response rate, and being faster and easier to administer [13]. The five parts of this study questionnaire are as follows: The first and second parts are concerned with the respondent's profile and the reaction to the impact of the COVID-19 pandemic on the income of small enterprises respectively. The third part examines the impact of Restrictions on Community Activities, namely whether or not the economic conditions of small companies are worsening. The fourth part discusses the forms of assistance that small businesses will receive during the COVID-19 pandemic. Finally, the change in respondents' responses to the benefits of e-commerce between before and during the COVID-19 pandemic.

The majority of data pertaining to SMEs is gathered and retained by parties with an interest in the SME. For example, the government, through the Indonesian Ministry of Cooperatives and Small Medium Enterprises, published data on small enterprise activities in specific areas. On the following website: https://kemenkopukm.go.id/, the data for this ministry can be obtained. The Republic of Indonesia's Law No. 20 of 2008 on micro, small, and medium-sized enterprises defined small enterprises as those with assets between 50 million and 500 million rupiahs, as well as revenue between 300 million and 2.5 billion rupiahs in a calendar year. Furthermore, owners of small enterprises or a group of employees are in charge of running them.

The descriptive analysis was conducted to explain the fundamental characteristics of the data: for example, frequency and other descriptive statistics were calculated. Following [38], descriptive statistics were employed to analyze the data, which was accomplished through the use of the SPSS program. Meanwhile, a description statistics dataset provides a legitimate and appropriate explanation of the study sample in numerical form, and the information is presented in the most straightforward manner possible. 
Furthermore, cross-tabulation is employed with data that can be categorized into mutually exclusive groups. This cross-tabulation is the most often used method of analysis [53]. In addition, a paired t-test was used to identify differences in the benefits obtained by small enterprises from the use of ecommerce. According to [54], [55], the paired t-test is used to test the null hypothesis that the average of the differences between pairs observations is zero. When observations are made on the same samples or subjects, they are paired. Furthermore, measurements were taken at two different times (before and during the COVID19 Pandemic), and the Paired Samples t-test compared the means for two units on a normally distributed continuous outcome. Null Hypothesis (Ho) means there is no difference in the average respondents' responses to the benefits of e-commerce between before and during the COVID-19 pandemic. Alternative Hypothesis (H1) means there is a difference in the average respondents' responses to the benefits of ecommerce between before and during the COVID19 pandemic.

\section{Results and Discussion}

There were 525 small enterprises as shown in Table 1. The majority of the gender were women consisting of 322 respondents or 61.3 percent, the remaining 203 were men. The age of the respondents is dominated by 20 to 30 years. Furthermore, about 257 (49 percent) and 228 (43.4 percent) had an education level of senior high school and Diploma/undergraduate respectively.
Table 1. Profile of respondents

\begin{tabular}{|l|l|l|}
\hline & $\begin{array}{l}\text { Frequen } \\
\text { cy }\end{array}$ & $\begin{array}{l}\text { Percentag } \\
\text { e (\%) }\end{array}$ \\
\hline Respondent's gender & & \\
\hline Male & 203 & 38.7 \\
\hline Female & 322 & 61.3 \\
\hline Respondent's age & & \\
\hline$<20$ & 35 & 6.7 \\
\hline $20-30$ & 321 & 61.1 \\
\hline $31-40$ & 120 & 22.9 \\
\hline $41-50$ & 36 & 6.9 \\
\hline$>50$ & 13 & 2.5 \\
\hline Respondent's education & & \\
\hline Primary school & 15 & 2.9 \\
\hline Junior high school & 16 & 3.0 \\
\hline Senior high school & 257 & 49 \\
\hline Diploma/Undergraduate & 228 & 43.4 \\
\hline Master/ Doctoral & 9 & 1.7 \\
\hline
\end{tabular}

The COVID-19 pandemic, as demonstrated in Table 2 showed a detrimental effect on small enterprises, particularly on income. This is demonstrated by the overwhelming majority that responded "yes." When asked, Is the COVID-19 pandemic reducing income? There is 84.6 percent of respondents answered "yes" while the remaining 15.4 percent answered "no". Small enterprises saw a loss in income of less than $10 \%$, accounting for 187 respondents. Meanwhile, small enterprises had a decrease in income of $10 \%$ to less than $25 \%$ for 170 respondents. These results are consistent with various surveys of SME businesses in various countries that have been negatively impacted by the COVID-19 pandemic [33], [34], [35], [36] and several studies on SMEs [9], [10], [37], [38].

Table 2. The Impact of the COVID-19 pandemic on Decreased Income

\begin{tabular}{|l|l|l|l|l|l|l|}
\hline \multirow{2}{*}{$\begin{array}{l}\text { Is the COVID-19 } \\
\text { pandemic } \\
\text { income? }\end{array}$} & Percentage of Income Decrease \\
\cline { 3 - 8 } & None & $<10 \%$ & $10 \%-<25 \%$ & $25 \%-<50$ & $>50 \%$ & Total \\
\hline Yes & 0 & 187 & 170 & 74 & 13 & 444 \\
& $(0.0 \%)$ & $(35.6)$ & $(32.4 \%)$ & $(14.1 \%)$ & $(2.5 \%)$ & $(84.6 \%)$ \\
\hline No & 81 & 0 & 0 & 0 & 0 & 81 \\
& $(15.4 \%)$ & $(0.0 \%)$ & $(0.0 \%)$ & $(0.0 \%)$ & $(0.0 \%)$ & $(15.4 \%)$ \\
\hline
\end{tabular}

The pandemic has impacted all aspects, but there is a larger concern about imposing restrictions to community activities measures that disproportionately harm SMEs [38], [39]. Table 3 showed respondents' reactions regarding the influence of community activity restrictions on the performance of small enterprises. Similarly, limitations on community activities impede the regular operation of small enterprises, resulting in a decline in demand and income. Restriction of community activities degrades the performance of small enterprises. This restriction aims to inhibit the spread of Covid-19, so that all non-essential businesses such as culinary businesses are "forced" to close their businesses. Strongly agree, slightly agree, and agree, dominated respondents' responses 
following the distribution of the percentage of the income decrease. This indicates that the Restrictions to Community Activities further worsen the performance of small enterprises.

Table 3. Impact of Restrictions to Community Activities based on Percentage of Income Decrease

\begin{tabular}{|c|c|c|c|}
\hline \multirow{2}{*}{$\begin{array}{l}\text { Percentage of } \\
\text { Income Decrease }\end{array}$} & \multicolumn{3}{|c|}{ Restrictions to Community Activities worsen small enterprise performance } \\
\hline & $\begin{array}{c}\text { Strongly } \\
\text { Disagree/ Disagree /Slightly } \\
\text { Disagree }\end{array}$ & $\begin{array}{l}\text { Neither } \\
\text { Agree nor } \\
\text { Disagree }\end{array}$ & $\begin{array}{c}\text { Slightly } \\
\text { Agree/Agree/Strongly } \\
\text { Agree }\end{array}$ \\
\hline$<10 \%$ & $\begin{array}{c}41 \\
(9.30 \%) \\
\end{array}$ & $\begin{array}{c}44 \\
(9.9 \%) \\
\end{array}$ & $\begin{array}{c}102 \\
(23 \%)\end{array}$ \\
\hline $10 \%-<25 \%$ & $\begin{array}{c}11 \\
(1.8 \%)\end{array}$ & $\begin{array}{c}21 \\
(4.7 \%)\end{array}$ & $\begin{array}{c}138 \\
(20.3 \%)\end{array}$ \\
\hline $25 \%-<50$ & $\begin{array}{c}4 \\
(1.00 \%) \\
\end{array}$ & $\begin{array}{c}8 \\
(1.8 \%)\end{array}$ & $\begin{array}{c}62 \\
(13.9 \%) \\
\end{array}$ \\
\hline$>50 \%$ & $\begin{array}{c}1 \\
(0.20 \%)\end{array}$ & $\begin{array}{c}0 \\
(0.0 \%)\end{array}$ & $\begin{array}{c}12 \\
(2.7 \%)\end{array}$ \\
\hline Total & $\begin{array}{c}57 \\
(12.9 \%) \\
\end{array}$ & $\begin{array}{c}73 \\
(16.4 \%)\end{array}$ & $\begin{array}{c}314 \\
(70.7 \%)\end{array}$ \\
\hline
\end{tabular}

Table 4 described the support required by small enterprises due to the COVID-19 pandemic. Working capital support accounts for the vast majority of the forms of assistance required. There were 238 respondents or 53.6 percent that chose working capital assistance. This result is consistent with the findings of [41], where the importance of liquidity assistance for SMEs was analyzed.

Table 4. Types of Assistance Required based on Percentage of Income Decrease Due to the COVID-19 pandemic

\begin{tabular}{|c|c|c|c|c|c|c|}
\hline \multirow{2}{*}{$\begin{array}{l}\text { Percentage of } \\
\text { Income } \\
\text { Decrease }\end{array}$} & \multicolumn{6}{|c|}{ Types of Assistance Required } \\
\hline & $\begin{array}{l}\text { Working } \\
\text { Capital } \\
\text { Assistance }\end{array}$ & $\begin{array}{l}\text { Ease of loan } \\
\text { application } \\
\text { administration }\end{array}$ & $\begin{array}{c}\text { Electricity } \\
\text { Bill } \\
\text { Reduction }\end{array}$ & $\begin{array}{l}\text { Tax Rate } \\
\text { Reduction }\end{array}$ & $\begin{array}{c}\text { Loan } \\
\text { Restructuring }\end{array}$ & Other \\
\hline$<10 \%$ & $\begin{array}{c}105 \\
(23.6 \%)\end{array}$ & $\begin{array}{c}15 \\
(3.4 \%)\end{array}$ & $\begin{array}{c}36 \\
(8.1 \%)\end{array}$ & $\begin{array}{c}10 \\
(2.3 \%)\end{array}$ & $\begin{array}{c}6 \\
(1.4 \%)\end{array}$ & $\begin{array}{c}15 \\
(3.4 \%)\end{array}$ \\
\hline $10 \%-<25 \%$ & $\begin{array}{c}92 \\
(20.7 \%)\end{array}$ & $\begin{array}{c}11 \\
(2.5 \%)\end{array}$ & $\begin{array}{c}36 \\
(8.1 \%)\end{array}$ & $\begin{array}{c}12 \\
(2.7 \%)\end{array}$ & $\begin{array}{c}10 \\
(2.3 \%)\end{array}$ & $\begin{array}{c}9 \\
(2.0 \%)\end{array}$ \\
\hline $25 \%-<50$ & $\begin{array}{c}35 \\
(7.9 \%)\end{array}$ & $\begin{array}{c}10 \\
(2.3 \%)\end{array}$ & $\begin{array}{c}10 \\
(2.3 \%)\end{array}$ & $\begin{array}{c}7 \\
(1.6 \%)\end{array}$ & $\begin{array}{c}8 \\
(1.8 \%)\end{array}$ & $\begin{array}{c}4 \\
(0.9 \%)\end{array}$ \\
\hline$>50 \%$ & $\begin{array}{c}6 \\
(1.4 \%)\end{array}$ & $\begin{array}{c}3 \\
(0.7 \%)\end{array}$ & $\begin{array}{c}0 \\
(0.0 \%)\end{array}$ & $\begin{array}{c}1 \\
(0.2 \%)\end{array}$ & $\begin{array}{c}3 \\
(0.7 \%)\end{array}$ & $\begin{array}{c}0 \\
(0.0 \%)\end{array}$ \\
\hline Total & $\begin{array}{c}238 \\
(53.6 \%) \\
\end{array}$ & $\begin{array}{c}39 \\
(8.8 \%) \\
\end{array}$ & $\begin{array}{c}82 \\
(18.5 \%) \\
\end{array}$ & $\begin{array}{c}30 \\
(6.8 \%) \\
\end{array}$ & $\begin{array}{c}27 \\
(6.1 \%) \\
\end{array}$ & $\begin{array}{c}28 \\
(6.3 \%) \\
\end{array}$ \\
\hline
\end{tabular}

Table 5 provided an overview of whether there are significant differences in the responses to the benefits of e-commerce. Generally, all respondents slightly agree, agree, and strongly agree about the benefits (extending market reach (EMR), reduced promotion cost (RPC), improved competitive position (ICP), payment transactions made simple (PTMS), increased customer loyalty and retention (ICLR), improved speed of processing (ISP), reduced complaints from the client (RCC), and reduced operation cost (ROC) for small enterprises. Furthermore, there is a shift in respondents' responses to the benefits of e-commerce for small enterprises during the COVID-19 pandemic to choose slightly agree, agree, and strongly agree. Before the COVID-19 pandemic, the majority of responses to the benefits of e-commerce also chose slightly agree, agree, and strongly agree. However, during the pandemic, there was a shift to slightly agree, agree, and strongly agree. More respondents voted slightly agree, agree, and strongly agree with the benefits of e-commerce for small enterprises.

There are significant differences in respondents' responses to the benefits of e-commerce through reduced promotion cost, improved competitive position, payment transactions made simple, 
increased customer loyalty and retention, improved speed of processing, reduced complaints from clients. This demonstrates that small firms who use e-commerce benefit both before and after the COVID-19 outbreak. Indeed, during the epidemic, restriction of community activities degrades social activities and increase in the percentage of persons who eat at home, so that operational activities such as promotions, payments and customer service are maximized through e-commerce.

The benefits in the form of extending the market reduced operation costs and showed no significant difference between before and during the COVID19 pandemic. The extending market reach and reduced operating costs are not significant because the scope of small enterprises of Indonesia is not too broad and the adoption for marketing activities is not to support production. These results are consistent with previous studies 13], [16], [17], [43], [44], [45], [ [46], [47], [48], [49], which showed the important role of e-commerce adoption in supporting small business performance. Generally, responses of respondents to slightly agree, agree, strongly agree increased. This showed the important role of e-commerce in providing benefits to small enterprises during the COVID-19 pandemic.

Table 5. Differences in respondents' responses to the benefits of e-commerce between before and during the COVID-19 pandemic

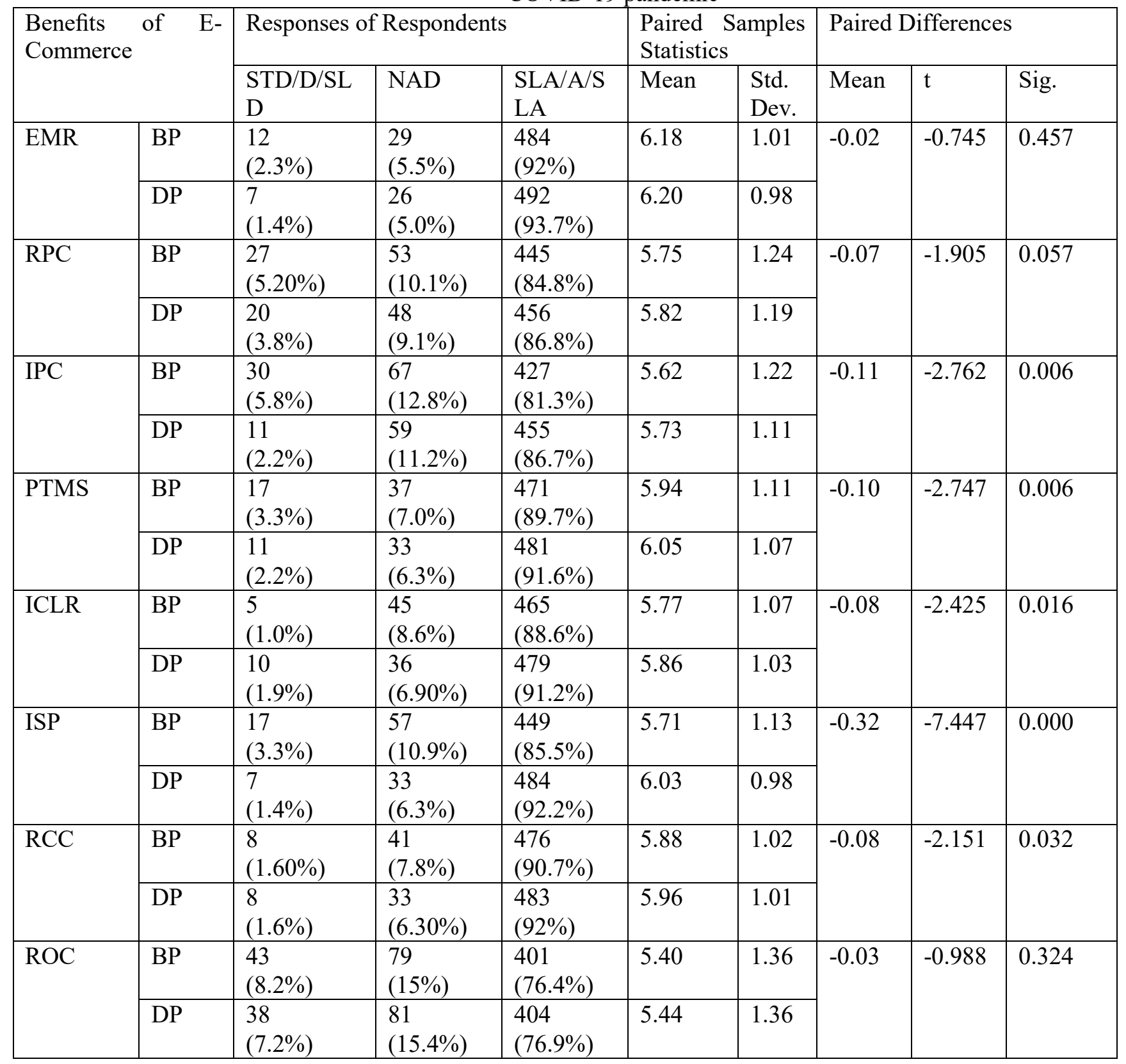


Note: $\mathrm{BP}=$ Before the COVID-19 pandemic; DP = During the COVID-19 pandemic; STD = Strongly Disagree; $\mathrm{D}=\mathrm{Disagree}$; SLD = Slightly Disagree; NAD = Neither Agree nor Disagree; STA = Strongly Agree; A = Agree; SLA = Slightly Agree .

\section{Conclusion}

This study offers an understanding of the benefits of e-commerce by small enterprises in developing countries, such as Indonesia, and its implications before and during the COVID-19 pandemic. Furthermore, it explores the effects on the decline of small enterprises' income and the response to the policy of restrictions for community activities. This study provides an overview of the types of assistance required through an online questionnaire survey conducted from May 2021 - June 2021 among small culinary businesses in Indonesia. Meanwhile, a descriptive analysis was conducted to explain the fundamental characteristics of the data. A paired t-test was also conducted to test for differences in respondents' responses to the benefits of e-commerce.

The results highlight important findings, such as the decrease in income due to the COVID-19 pandemic (35.6 percent of respondents experienced a decrease of less than 10 percent and 32.4 percent experienced a decrease in income of 10 to less than 25 percent). The restrictions on community activities further worsen the performance of small enterprises. Furthermore, 70.7 percent of respondents agreed that restrictions to community activities further worsen the performance. In response to the COVID-19 pandemic, small companies have relied on a variety of different types of help, with working capital support accounting for the great bulk of those requests. Finally, there are significant differences to the benefits of e-commerce between before and during the COVID-19 pandemic (reduced promotion cost, improved competitive position, payment transactions made simple, increased customer loyalty and retention, improved speed of processing, reduced complaints from the client).

The study has several significant policy implications, and the results provide empirical evidence for the benefits of e-commerce. This condition undoubtedly has implications for the government's ability to be more effective in encouraging small businesses to adopt e-commerce, particularly during time of health crisis. This is due to the low adoption of e-commerce by small enterprises and the uneven distribution of supporting infrastructure such as connectivity and internet access in Indonesia.

Moreover, since the study area is limited to a single country, a future survey should be conducted to expand the sample on a global scale. Since the study is focused on small culinary businesses, additional studies are therefore recommended.

\section{References:}

[1] Briozzo, A., \& Cardone-Riportella, C. Evaluating the impact of public programs of financial aid to SMEs during times of crisis: The Spanish experience. Working Papers 12.04. Seville, Spain: Department of Financial Economics and Accounting, Universidad Pablo de Olavide, 2012.

[2] Yoshino, N., \& Taghizadeh-Hesary, F., The role of SMEs in Asia and their difficulties in accessing finance. Asian Development Bank Institute. ADBI Working Papers, 2018.

[3] Kaya, H.P., \& Uzay. S. 2017. The risks that will threaten going concern and control recommendations: Case study on SMEs. The Journal of Accounting and Finance, 2017, Special Issue: 46-64.

[4] Garcia, L. M. V., Jacanamejoy, J. D. P., Cordoba, M. A. H., \& Lopez, J. M.G., Factors that influence the competitiveness of SMEs in the commerce and services sector in the Municipality of Palmira, Colombia. Problems and Perspectives in Management, Vol 17, No 4, 2019, pp. 480-492.

[5] Sharma, M.K., \& Bhagwat, R., Practice of information systems: Evidence from select Indian SMEs. Journal of Manufacturing Technology Management, Vol 17, No 2, 2006, pp.199-223.

[6] Meher, B. K., Hawaldar, I. T., Mohapatra, L., Spulbar, C., Birau, R., \& Rebegea, C., The impact of digital banking on the growth of Micro, Small and Medium Enterprises MSMEs in India: a case study. Business: Theory and Practice, Vol 22, No 1, 2021, pp. 18-28.

[7] Moussa, F., Impact of microfinance loans on the performance of SMEs: the case of Lebanon. Business: Theory and Practice, Vol 21, No 2, 2020, pp. 769-779.

[8] Yudaruddin, R. Determinants of micro-, smalland medium-sized enterprise loans by commercial banks in Indonesia. Journal of Asian Finance, Economics and Business, Vol 7, No 9, 2020, pp. 19-30.

[9] Tairas, D. R. Covid-19 pandemic and MSMEs: Impact and mitigation. Jurnal 
Ekonomi Indonesia, Vol 9, No 1, 2020. pp. 67-80.

[10] Hermina, N., Syahvianto, T. M., \& Yansa, B., Second Order Model Structural Equation Modeling for Analyzing External Environmental and Capability on Company Performance of Small and Medium Enterprise SME in Indonesia, PalArch's Journal of Archaeology of Egypt / Egyptology, Vol 17, No 5, 2020, pp. 3718-3731.

[11] BPS, Analisis Hasil SE2016 Lanjutan Potensi Peningkatan Kinerja Usaha Mikro Kecil. Badan Pusat Statistik. Indonesia, 2019.

[12] Deloitte, Realising the potential of Indonesia's digital economy. Deloitte Indonesia Perspectives. Second Edition, February 2021. 2021.

[13] Rahayu, R., \& Day, J., E-commerce adoption by SMEs in developing countries: evidence from Indonesia. Eurasian Business Review, Vol 7, No 1, 2017, pp. 25-41.

[14] Breckova, P., \& Karas, M., Online technology and promotion tools in SMEs. Innovative Marketing, Vol 16, No 3, 2020, pp. 85-97.

[15] Brewera, P., \& Sebby, A. G., The effect of online restaurant menus on consumers' purchase intentions during the COVID-19 pandemic. International Journal of Hospitality Management, Vol 94, 2020, 102777.

[16] Syaifullah, J., Syaifudin, M., Sukendar, M. U., \& Junaedi, J., Social Media Marketing and Business Performance of MSMEs During the COVID-19 Pandemic. Journal of Asian Finance, Economics and Business, Vol 8, No 2, 2021, pp. 523-531.

[17] Alheet, A. F., Hamdan, Y., AL-Bazaiah, S. A., The Impact of Technology, Entrepreneurship and Consumer Attitudes on Firm Performance. Polish Journal of Management Studies, Vol 23, No 1, 2021, pp. 23-44.

[18] Ho, L. 2011. Meditation, learning, organizational innovation and performance, Industrial Management \& Data Systems, Vol 111, No 1, 2011, pp. 113-131.

[19] Molla, A., \& Heeks, R., Exploring ECommerce Benefits for Businesses in a Developing Country. The Information Society, Vol 23, No 2, 2007, pp. 95-108.

[20] Papadopoulos, T., Baltas, K. N., Balta, M. E. The use of digital technologies by small and medium enterprises during COVID-19: implications for theory and practice. International Journal of Information Management, Vol 55, 2020, 102192.
[21] Botha, J.A.R., Bothma, C.H., Geldenhuys, P., Singh, A.M., Van Der Merwe, D., Booysen, H. $\&$ Fourie, I. Managing E-commerce. Paarl: Juta $\& \mathrm{Co}, 2004$.

[22] Turban, E., Electronic commerce 2010: a managerial perspective. Upper Saddle River: Pearson Education. 2010.

[23] Li, P., \& Xie, W., A strategic framework for determining e- commerce adoption. Journal of Technology Management in China, Vol 7, No 1, 2012, pp. 22-35.

[24] Laudon, K. C., \& Traver, C. G., E-Comerse 2016 business, tecnology, sociey 12th ed. England: Britis Library Cataloguint-in. 2017.

[25] Fishbein, M., \& Ajzen, I. Belief, Attitude, Intention, and Behavior: An Introduction to Theory and Research. Reading, MA: AddisonWesley, 1975.

[26] Ajzen, I. The theory of planned behavior. Organizational Behavior and Human Decision Processes, Vol 50, 1991, pp. 179-211.

[27] Davis, F. D. Perceived Usefulness, Perceived Ease of Use, and User Acceptance of Information Technology. MIS Quarterly, Vol 13, No 5, 1989, pp. 319-339.

[28] Rogers, E. Diffusion of innovations, New York: The Free Press. 1983.

[29] Tornatzky, L.G., Fleischer, M. and Chakrabarti, A.K., Processes of Technological Innovation. Lexington Books, Lexington. 1990.

[30] Chatterjee, R., K. Shiwaku, R.D. Gupta, G. Nakano, \& Shaw. R., Bangkok to Sendai and beyond: Implications for disaster risk reduction in Asia. International Journal of Disaster Risk Science, Vol 6, No 2, 2015. pp. 177-188.

[31] Igwe, P.A., Amaugo, A.N., Ogundana, O.M., Egere, O.M. \& Anigbo, J.M., Factors affecting the investment climate, SMEs productivity and entrepreneurship in Nigeria. European Journal of Sustainable Development, Vol 71, No 1, 2018, pp. 182-200.

[32] Mbuyisa, B., \& Leonard, A., The role of ICT use in SMEs towards poverty reduction: A systematic literature review. Journal of International Development, Vol 29, No 2, 2017, pp.159-19.

[33] Bartik, A. W., Bertrand, M., Cullen, Z. B., Glaeser, E. L., Luca, M., \& T. Stanton, C. T. How Are Small Businesses Adjusting to Covid19? Early Evidence from A Survey, NBER Working Paper Series, No. 26989, 2020.

[34] Humphries, J. E, Neilson, C. and Ulyssea, G., The Evolving Impacts of COVID-19 on Small Businesses Since the CARES Act. Cowles 
Foundation Discussion Paper, No. 2230, Cowles Foundation. 2020.

[35] McKinsey, Which small businesses are most vulnerable to COVID-19--and when, 2020.

[36] Buffington, C., Dennis, C., Dinlersoz, E., Foster, L. and Klimek, S., Measuring the Effect of COVID-19 on U.S. Small Businesses: The Small Business Pulse Survey. No. CES-20-16, US Census Bureau. 2020.

[37] Ssenyonga, M., Imperatives for post COVID19 recovery of Indonesia's education, labor, and SME sectors. Cogent Economics \& Finance, Vol 9, 2021, 1911439.

[38] Lutfi, M., Buntuang, P. C. D., Kornelius, Y., Erdiyansyah \& Hasanuddin, B., The impact of social distancing policy on small and mediumsized enterprises SMEs in Indonesia. Problems and Perspectives in Management, Vol 18, No 3, 2020, pp. 492-503.

[39] Thorgren, S. Williams, T. A., Staying alive during an unfolding crisis: How SMEs ward off impending disaster, Vol 14, 2020 , e00187.

[40] Gourinchas P., Kalemli-zcan, S., Penciakova, V., Sander, N., COVID-19 and SME Failures, NBER Working Papers 27877, National Bureau of Economic Research, Inc. 2020.

[41] Liu, S., Parilla, J. Businesses owned by women and minorities have grown. Will COVID-19 undo that? Brookings. 2020.

[42] Bircan, Ç., De Haas, R., Schweiger, H., Stepanov, A., Coronavirus credit support: Don't let liquidity lifelines become a golden noose. Voxeu, 2020.

[43] Hempel, P.S. and Kwong, Y.K. B2B eCommerce in emerging economies: i-metal. com's non-ferrous metals exchange in China, The Journal of Strategic Information Systems, Vol 10, No 4, 2001, pp. 335-55.

[44] Chwelos, P., Benbasat, I. and Dexter, A.S., Research report: empirical test of an EDI adoption model. Information Systems Research, Vol 12, No 3, 2001, pp. 304-21.

[45] Antoniuk, L., Gernego, I., Dyba, V., Polishchuk, Y., \& Sybirianska, Y., Barriers and opportunities for hi-tech innovative small and medium enterprises development in the 4th industrial revolution era. Problems and Perspectives in Management, Vol 15, No 4, 2017, pp. 100-113.

[46] Fatta, D. D., Patton, D, \& Viglia, G., The determinants of conversion rates in SME ecommerce websites. Journal of Retailing and Consumer Services, Vol 4, No 1, 2018, pp. 161-168.
[47] Waseem, A., Rashid, Y., Warraich, M. A., Sadiq, I. \& Shaukat, Z., Factors affecting Ecommerce potential of any country using multiple regression analysis. Journal of Internet Banking and Commerce, Vol 24, No 2, 2019, pp. $1-28$.

[48] Ajibade, P., Ondari-Okemwa, E. M. \& Matlhako, M. M., Information technology integration for accelerated knowledge sharing practices: challenges and prospects for small and medium enterprises. Problems and Perspectives in Management, Vol 17, No 4, 2019, pp. 131-140.

[49] Alzahrani, J., The impact of e-commerce adoption on business strategy in Saudi Arabian small and medium enterprises SMEs. Review of Economics and Political Science, Vol 4, No 1, 2019, pp. 73-88.

[50] Nooteboom, B., Transaction Costs, Innovation and Learning. CentER Discussion Paper; Vol. 2006-36. Tilburg: Organization. 2006.

[51] Tapscott, D. Rethinking strategy in a networked world or why Michael Porter is wrong about the internet. Strategy and Business, 2001, 34-41.

[52] Hamad, H., Elbeltagi, I. and El-Gohary, H., An empirical investigation of business-to business e-commerce adoption and its impact on SMEs competitive advantage: the case of Egyptian manufacturing SMEs. Strategic Change, Vol 27, No 3, 2018, pp. 209-229.

[53] Yudaruddin, R. Statistik Ekonomi: Aplikasi Dengan Program SPSS Versi 20. Interpena Yogyakarta. 2014.

[54] David, I., Adubisi, O., Farouk, B., \& Adehi, M., Assessing MSMEs Growth Through Rosca Involvement Using Paired t-Test and One Sample Proportion Test. Journal of Social and Economic Statistics, Vol 9, No 2, 2020, pp. 3042.

[55] Diepa, B. H. \& Anh, T. T., Synergies in merger \& acquisition: A case study of SMEs in Vietnam. Journal of Project Management, Vol 5, 2020, pp.189-200.

[56] Yudaruddin, R. Determinants of corporate cash holdings: Evidence of the mining sector in Indonesia. International Journal of Scientific \& Technology Research, Vol 8, No, 10, 2019, pp. 1523-1526.

[57] Kusumawardani, A., Yudaruddin, R., \& Yudaruddin, Y. A. Corporate Governance's Policy on the Impact of Cash Holding in Indonesia. Universal Journal of Accounting and Finance, Vol 9, No 4, 2021, pp. $594-603$. 
[58] Hadjaat, M., Yudaruddin, R., \& Riadi, S. S. The Impact of Financial Distress on Cash Holdings in Indonesia: Does Business Group Affiliation Matter? Journal of Asian Finance, Economics and Business, Vol 8, No 3, 2021, pp. 373-381.

\section{Contribution of Individual Authors to the Creation of a Scientific Article (Ghostwriting Policy)}

Sukisno Selamet Riadi is tasked with oversight. Ariesta Heksarini conceptualized the work.

Dirga Lestari is in charge of data curation.

Siti Maria is responsible for methodology.

Saida Zainurossalamia is in charge of writing the initial draft.

Rizky Yudaruddin is in charge of editing and proofreading tasks.

\section{Creative Commons Attribution License 4.0}

\section{(Attribution 4.0 International, CC BY 4.0)}

This article is published under the terms of the Creative Commons Attribution License 4.0

https://creativecommons.org/licenses/by/4.0/deed.en $\underline{\underline{U S}}$ 